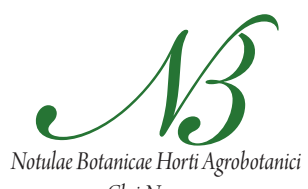

Cluj-Napoca

\title{
G x E Interaction on Yield Stability of Five Sweet Corn Hybrids Grown under Different Agricultural Systems
}

\author{
Marin ARDELEAN ${ }^{1}$, Mirela CORDEA ${ }^{1 *}$, Voichița HAŞ², Agnes BORS \\ ${ }^{1}$ University of Agricultural Sciences and Veterinary Medicine Cluj-Napoca, Faculty of Horticulture, 3-5 \\ Mănăştur Street, 400372, Cluj, Romania; mirelacordea@yahoo.co.uk (*correspondingauthor) \\ ${ }^{2}$ Agricultural Research and Development Station Turda, 27 Agriculturii Street. 401100 Turda, Romania
}

\begin{abstract}
Yield stability in sweet corn and its dependence on G x E interaction were investigated in a series of two way experiments. Five Romanian sweet corn hybrids were tested in three years (2008-2010) in three locations of Central Transylvania in different soils and climatic conditions. The experiments were organized in a split plot design in which, on a general level of organic fertilization ( $40 \mathrm{t} / \mathrm{ha}$ manure), four levels of mineral $\mathrm{N}$ fertilization were applied $\left(\mathrm{kg} / \mathrm{ha}\right.$, active matter): $\mathrm{N}_{0}$, typical for organic technologies; $\mathrm{N}_{50}$, corresponding to the low-input (sustainable) system; $\mathrm{N}_{100}$ and $\mathrm{N}_{150}$ customary with conventional system of agriculture. Based on ear yield data registered for hybrids in locations $x$ years $x$ cropping system, a phenotypic index $\left(\mathrm{P}_{\mathrm{i}}\right)$ was computed for each sweet corn hybrid illustrating the stability of their cob yields, with and without husks. The share of genotypic and $\mathrm{G} x \mathrm{E}$ effects in the total value of $\mathrm{P}_{\mathrm{i}}$ have been estimated. In different agricultural systems the tested hybrids were classified differently based on their $\mathrm{P}_{\mathrm{i}}$ values. It is concluded that, at least for the time being, the initiation of an organic breeding program for sweet corn, in Romania, is not economically justified since all semiearly and semilate tested hybrids yielded satisfactorily under organic agricultural practices. Moreover, among the recently released sweet corn hybrids one can find certain genotypes highly suitable to organic (i.e. 'Deliciul verii, 'Estival') or low input ('Dulcin', 'Estival') agricultural practices. These three hybrids recorded the highes ear yields (with and without husks) over years, locations and agricultural systems.
\end{abstract}

Keywords: ear yield, G and G x E effects, $\mathrm{P}_{\mathrm{i}}$ index of stability, sweet corn

\section{Introduction}

In spite of the fact that in normal corn $\mathrm{G} x \mathrm{E}$ effects on yield (Khaldun et al., 2010; Tonk Fatma et al., 2011) and on other important characters such as stem borer resistance (Beyene et al., 2011) or intercropping practices (O'Leary and Smith, 1999) have been exhaustively analyzed by numerous papers, in sweet corn such research results have been rather scarce (Bachireddy et al., 1992; Has and Has, 2009) in comparison to other vegetables, most probably due to the rather low economic importance of this crop. The results of the mentioned papers show rather high values of $\mathrm{G} \times \mathrm{E}$ interaction effects upon the stability of the studied characters which make the approach of such research works quite suitable foe phenotypic selection of the new sweet corn hybrids. The recent trends of significant extension of sweet corn in Europe (www.agpm. corn/en/mais_doux.php) has emphasized once more the importance of $\mathrm{G} \times \mathrm{E}$ interaction in measuring varietal stability and the suitability of sweet corn hybrids for cultivation across seasons and ecological zones. This necessity becomes even more pressing due to the recent interest of organic and low input farmers in growing sweet corn both for fresh market and for canning industry. Thus, apart from the natural environmental variables (seasons and ecological areas), new technological variables have to be considered in measuring the stability of performances of the existing sweet corn cultivars.

The main objective of this study has been to evaluate the importance of Lin and Binns' index of superiority $\left(\mathrm{P}_{\mathrm{i}}\right)$, especially when it is integrated with yield, for simultaneous selection of high yielding and stable sweet corn genotypes, when $\mathrm{G} x \mathrm{E}$ interaction proves significant.

\section{Materials and methods}

Five Romanian sweet corn hybrids ('Prima', 'Estival', 'Deliciul verii', 'Dulcin' and 'T-145') released by the Agricultural Research Station, Turda, Romania, were tested in three years (2008-2010) in three locations of Central Transylvania: Turda ( $46^{\circ} 34^{\prime} 15^{\prime \prime} \mathrm{N}$ and $\left.23^{\circ} 46^{\prime} 45^{\prime \prime} \mathrm{E}\right)$, with chernozem soils, annual mean temperature of $8.9^{\circ} \mathrm{C}$ and $513.6 \mathrm{~mm}$ of rainfalls; Jucu $\left(46^{\circ} 51^{\prime} 18^{\prime \prime} \mathrm{N}\right.$ and $\left.23^{\circ} 47^{\prime} 35^{\prime \prime} \mathrm{E}\right)$, with sandy loam soil, annual mean temperature of $8.3^{\circ} \mathrm{C}$ and $612.7 \mathrm{~mm}$ of rainfalls and Morău (46.59'49" $\mathrm{N}$ and $23^{\circ} 44^{\prime} 35^{\prime \prime} \mathrm{E}$ ), with brown reddish soils-preluvisoil, annual mean temperature of $8.0^{\circ} \mathrm{C}$ and $560.1 \mathrm{~mm}$ of rainfalls, all in Cluj County).

The experiments were organised in a split plot design in which, on a general level of organic fertilization ( $40 \mathrm{t}$ / ha manure), four levels of mineral $\mathrm{N}$ fertilization were applied ( $\mathrm{kg} / \mathrm{ha}$, active matter): $\mathrm{N}_{0}$, typical for organic tech- 
nologies; $\mathrm{N}_{50}$, corresponding to the low-input (sustainable) system; $\mathrm{N}_{100}$ and $\mathrm{N}_{150}$ customary with conventional system of agriculture. The specific technologies of weed and pest control were applied in each agricultural system.

Based on cob yield data registered for hybrids in locations $\mathrm{x}$ years $\mathrm{x}$ cropping system, a superiority index $(\mathrm{Pi})$ was computed for each sweet corn hybrid, illustrating the stability of their cob yields, with and without husks. Lin and Binns' (1988) procedure and formula were used to compute $\mathrm{P}$

$$
\begin{aligned}
& \mathrm{P}_{\mathrm{i}}=\left[n\left(\bar{X}_{i}-\bar{M}\right)^{2}+\sum_{j=1}^{q}\left(X_{i j}-\bar{X}_{i}-M_{j}+\bar{M}\right)^{2}\right] / 2 n \\
& \text { in which: }
\end{aligned}
$$

$\bar{X}_{i}=$ mean yield of ith cultivar in $\mathrm{n}$ environments; $\bar{M}=$ mean of maximum yields in n environments; $M_{j}=$ maximum yield of all cultivars in the $j^{\text {th }}$ environment; $X_{i j}$ $=$ yield of $\mathrm{i}^{\text {th }}$ cultivar in the $\mathrm{j}^{\text {th }}$ environment; $\bar{X}_{i}=$ mean yield of all cultivars in all environments; $n=$ number of environments.

$P_{i}$ is the measure of deviation of performances of a certain genotype from the maximum value of the studied character (i.e. cob yield) across all environments. Thus, the cultivar with the lowest $P_{i}$ value will be considered the most stable one, the most adapted to the various environments in which the experiment has been performed. The authors consider that the first part of the above formula is quantifying the contribution of genotype $(G)$ while the second part is indicating the share of $G \times E$ to the total value of $P i$. On this basis the shares of genotypic $(G)$ and $G \times$ E effects in the total value of $P$ has been evaluated. For each tested genotype, $P_{i}$ and cob yields (with and without husks) were graphically presented vs. mean values of $\mathrm{P}_{\mathrm{i}}$ and yield across years, locations and levels of mineral $\mathrm{N}$ fertilization.

\section{Results and discussion}

It is well known the fact that sweet corn yields poorer than the normal one (Hemphill and Hart, 1992; Salardini et al., 1992) but nevertheless it can yield as high as $35-40$ t/ha unhusked cobs (Has, 2002) on condition that its needs of nitrogen are properly supplied (Ardelean et al., 2010). Since, in Romania, sweet corn is consumed mainly as fresh vegetable (boiled ears), farmers are less interested in husked ear yield and more attentive to produce great number of marketable ears/ha. Tab. 1 shows the yield performances ( $t /$ ha unhusked ears) of the tested sweet corn hybrids grown on different levels of mineral $\mathrm{N}$ fertilization as well as their index of superiority and the shares of $\mathrm{G}$ and $\mathrm{G} \times \mathrm{E}$ in the total value of these indices. As it has been expected, 'Prima' cv. registered the poorest yields, most probably due to its earliness, which did not allow the plants to use the additional mineral $\mathrm{N}$ fertilization. Even on $\mathrm{N}_{100}$ and $\mathrm{N}_{150}$ this genotype has an unhusked ear yield which differs from that registered on $\mathrm{N}_{0}$ only slightly above the limits of $\mathrm{P}_{5 \%}$.

The highest unhusked ear yields were noticed in semiearly and semilate hybrids (26.2-29.0 t/ha) with high and very high rates of additional mineral $\mathrm{N}$ fertilization $\left(\mathrm{N}_{100}\right.$ and $\left.\mathrm{N}_{150}\right)$. It is worth mentioning the fact that in 'Deliciul verii' $\mathrm{cv}$. (semilate) the increase of additional mineral $\mathrm{N}$, from $\mathrm{N}_{0}$ to $\mathrm{N}_{50}$ and from $\mathrm{N}_{50}$ to $\mathrm{N}_{150}$, was not accompanied by significant increases of unhusked ear yields. Theses results might suggest that for certain sweet corn genotypes, the fertilization with high and very high rates of additional mineral $\mathrm{N}$ might not be economically efficient since the yield increase is far from being significant as compared with yield obtained with low rates of

\begin{tabular}{|c|c|c|c|c|c|c|c|c|c|c|c|c|}
\hline \multirow[b]{2}{*}{ Hybrid } & \multicolumn{4}{|c|}{$\operatorname{Organic}\left(\mathrm{N}_{0}\right)$} & \multicolumn{4}{|c|}{ Low input $\left(\mathrm{N}_{50}\right)$} & \multicolumn{4}{|c|}{ Conventional (mean $\left.\mathrm{N}_{100}-\mathrm{N}_{150}\right)$} \\
\hline & $\begin{array}{l}\text { Yield } \\
\text { t/ha }\end{array}$ & $\mathrm{P}_{\mathrm{i}}$ & G effect & $\begin{array}{l}\text { GxE } \\
\text { effect }\end{array}$ & $\begin{array}{l}\text { Yield } \\
\text { t/ha }\end{array}$ & $\mathrm{P}_{\mathrm{i}}$ & G effect & $\begin{array}{l}\text { GxE } \\
\text { effect }\end{array}$ & $\begin{array}{l}\text { Yield } \\
\text { t/ha }\end{array}$ & $\mathrm{P}_{\mathrm{i}}$ & G effect & $\begin{array}{l}\text { GxE } \\
\text { effect }\end{array}$ \\
\hline 'Prima' & $17.0 \mathrm{f}$ & 35.3 & 25.4 & 9.8 & $18.1 \mathrm{ef}$ & 30.9 & 14.6 & 16.3 & $20.3 \mathrm{de}$ & 37.1 & 17.7 & 19.5 \\
\hline 'Dulcin' & $20.0 \mathrm{de}$ & 16.2 & 8.4 & 7.8 & $22.2 \mathrm{~cd}$ & 21.6 & 5.2 & 16.4 & $26.2 \mathrm{ab}$ & 3.1 & 0.4 & 2.7 \\
\hline 'Estival' & $21.1 \mathrm{~cd}$ & 8.6 & 4.7 & 3.9 & $22.9 \mathrm{~cd}$ & 18.3 & 4.8 & 13.5 & $26.7 \mathrm{a}$ & 1.4 & 0.2 & 1.2 \\
\hline 'Deliciul verii' & $23.4 \mathrm{bc}$ & 10.7 & 0.2 & 10.5 & $26.0 \mathrm{ab}$ & 18.6 & 1.4 & 17.2 & $29.0 \mathrm{a}$ & 11.3 & 4.9 & 6.5 \\
\hline 'T-145’ & $19.2 \mathrm{ef}$ & 16.1 & 12.1 & 4.0 & $23.5 \mathrm{bc}$ & 18.7 & 3.9 & 14.8 & $26.6 \mathrm{a}$ & 14.6 & 5.8 & 8.8 \\
\hline
\end{tabular}

Tab. 1. Unhusked ear yields ( $t / h a)$ and their index of superiority $\left(\mathrm{P}_{\mathrm{i}}\right)$

$\mathrm{SD}_{5 \%}$ for two hybrid $\mathrm{x}$ fertilization means: $2.9-3.7 \mathrm{t} / \mathrm{ha}$. The difference between any two values, followed by at least a common letter, is not significant

\begin{tabular}{|c|c|c|c|c|c|c|c|c|c|c|c|c|}
\hline \multirow[b]{2}{*}{ Hybrid } & \multicolumn{4}{|c|}{$\operatorname{Organic}\left(\mathrm{N}_{0}\right)$} & \multicolumn{4}{|c|}{ Low input $\left(\mathrm{N}_{50}\right)$} & \multicolumn{4}{|c|}{ Conventional (mean $\mathrm{N}_{100}-\mathrm{N}_{150}$ ) } \\
\hline & $\begin{array}{l}\text { Yield } \\
\text { t/ha }\end{array}$ & $\mathrm{P}_{\mathrm{i}}$ & $\begin{array}{c}\text { G } \\
\text { effect }\end{array}$ & $\begin{array}{l}\text { GxE } \\
\text { effect }\end{array}$ & $\begin{array}{l}\text { Yield } \\
\text { t/ha }\end{array}$ & $\mathrm{P}_{\mathrm{i}}$ & $\begin{array}{c}\text { G } \\
\text { effect }\end{array}$ & $\begin{array}{l}\text { GxE } \\
\text { effect }\end{array}$ & $\begin{array}{l}\text { Yield } \\
\text { t/ha }\end{array}$ & $\mathrm{P}_{\mathrm{i}}$ & $\begin{array}{c}\text { G } \\
\text { effect }\end{array}$ & $\begin{array}{l}\mathrm{GxE} \\
\text { effect }\end{array}$ \\
\hline 'Prima' & $12.4 \mathrm{~g}$ & 34.4 & 26.6 & 7.8 & $13.2 \mathrm{~g}$ & 30.9 & 21.3 & 9.7 & $14.7 \mathrm{fg}$ & 32.5 & 15.7 & 16.8 \\
\hline 'Dulcin' & $15.9 \mathrm{ef}$ & 15.9 & 12.9 & 5.7 & $18.3 \mathrm{cde}$ & 18.6 & 10.9 & 7.7 & $20.7 \mathrm{ab}$ & 2.8 & 0.2 & 2.5 \\
\hline 'Estival' & $17.2 \mathrm{cde}$ & 17.4 & 9.4 & 8.0 & $19.2 \mathrm{bc}$ & 14.3 & 6.5 & 7.8 & $21.4 \mathrm{ab}$ & 1.5 & 0.6 & 0.9 \\
\hline 'Deliciul verii' & $18.4 \mathrm{cde}$ & 13.0 & 6.3 & 6.7 & $18.2 \mathrm{cde}$ & 13.1 & 4.8 & 8.3 & $22.6 \mathrm{a}$ & 8.1 & 3.1 & 4.9 \\
\hline 'T-145’ & $16.3 \mathrm{ef}$ & 18.5 & 11.7 & 6.8 & $18.8 \mathrm{bcd}$ & 10.7 & 4.8 & 5.9 & $21.4 \mathrm{ab}$ & 9.8 & 4.1 & 5.7 \\
\hline
\end{tabular}

Tab. 2. Husked ear yields $(\mathrm{t} / \mathrm{ha})$ and their index of superiority $\left(\mathrm{P}_{\mathrm{i}}\right)$

$\mathrm{SD}_{5 \%}$ for two hybrid $\mathrm{x}$ fertilization means: $2.9-3.7 \mathrm{t} / \mathrm{ha}$. The difference between any two values, followed by at least a common letter, is not significant 
292

mineral N. Such genotypes are highly suitable both for organic and low input agricultural technologies.

In different agricultural systems, the tested hybrids were classified differently on the basis of their $\mathrm{P}_{\mathrm{i}}$ values. Thus, in the organic system, 'Estival' and 'Deliciul verii' showed the lowest $P_{i}$ values (the highest stability) for unhusked ear yield, but in 'Deliciul verii', with the highest ear yield, the share of genotypic effects was very small while in 'Estival' the genotypic and G x E effects were approximately equal. In the sustainable subsystem three hybrids ('Dulcin', 'Estival' and 'Deliciul verii') showed the highest stability of their approximately equal levels of unhusked ear yields while under conventional practices of mineral $\mathrm{N}$ fertilization 'Estival' and 'Dulcin' ranked as the most stable genotypes for unhusked ear yield.

For the husked ear yield (Tab. 2), the only efficient yield levels $(\mathrm{t} / \mathrm{ha})$ were registered in the conventional system of $\mathrm{N}$ fertilization, both organic and sustainable practices presenting significantly lower values for this character. The stability of husked ear yield proved the highest in 'Estival' and 'Dulcin' under conventional practices of $\mathrm{N}$ fertilization while in organic and low input systems 'Deliciul verii' showed the grater yield stability. It could be stated that for husked ear yield, organic and low input farmers should prefer 'Deliciul verii' which can yield at the same level with 'Eestival' and 'Dulcin' being at the same time 5-6 days earlier and rather stable in its yielding behavior.

\section{Conclusions}

For the tested sweet corn hybrids, the conventional practices of mineral $\mathrm{N}$ fertilization should consider as really efficient only high rates of additional mineral $\mathrm{N}\left(\mathrm{N}_{150}\right)$. The low input practices of $\mathrm{N}$ fertilization $\left(\mathrm{N}_{50}\right)$ applied to these hybrids are far from rewarding the farmer with significant yield increases in comparison with no mineral $\mathrm{N}$ application.

Early genotypes (i.e. 'Prima') register poor ear yields (with and without husks), in all agricultural systems most probably due to their short vegetative period which does not allow the plants to use the additional mineral $\mathrm{N}$ fertilization.

For certain semiearly sweet corn genotypes, the fertilization with high and very high rates of additional mineral $\mathrm{N}$ might not be economically efficient since the yield increase is far from being significant as compared with yield obtained with low rates or no mineral $\mathrm{N}$ fertilization. Such genotypes (i.e. 'Deliciul verii') are highly suitable both for organic and low input agricultural technologies.

There could be stated that, at least for the time being, the initiation of an organic breeding program for sweet corn, in Romania, is not economically justified, since among the recently released sweet corn hybrids one can find certain genotypes (i.e. 'Estival,' 'Deliciul verii', 'Dulcin') rather highly adapted to organic or low input agri- cultural practices. The yield stability of these hybrids was significantly high over locations, years and $\mathrm{N}$ fertilization practices in different agricultural systems.

\section{Acknowledgements}

This paper is based on results obtained in the CNCSIS project ID no. 1489/2009 financed by the Ministry of Education, Research, Youth and Sports, Romania.

\section{References}

Ardelean M, Cordea M, Haş V, Bors A (2010). Yield and kernel quality performances of five sweet corn hybrids grown in conventional and organic systems of agriculture. Proc of ISHS Congress, Lisbon.

Bachireddy VR, Payne R Jr, Chin KL, Kang MS (1992). Conventional selection versus methods that use genotype $\mathrm{x}$ environment interaction in sweet corn trials. Hort Sci 27(5):436-438.

Beyene Y, Mugo S, Mutinda Ch, Tefera T, Karaya H, Ajanga S, ShumaJ, Tende R, Kega V (2011). Genotype by environment interactions and yield stability of stem borer resistant maize hybrids in Kenya. Afr J Biotechnol 10(23):4752-4758.

Haş V (2002). Fresh market sweet corn production, 213-218 p. In: Biotechnology and biodiversity. Ed. Agroprint Timişoara (in Romanian).

Haş V, Haş I (2009). Genetic inheritance of some important characters of sweet corn. Not Bot Horti Agrobo 37(1):244248.

Hemphill D, Hart J (1992). Nitrogen rate, form and placement on sweet corn yield and nitrogen uptake. Oregon State Univ. http://groups.hort.oregonstate.edu/content/nitrogenrate-form-and-placement-sweet-corn-yield-and-nitrogenuptake-1992.

Khaldun ABM, Salauddin A, Shalim Uddin M, Abu Alam M, Mahfuzul Haque M, Islam MA (2010). Analysis of genotype environment interaction in hybrid popcorn genotypes (Zea mays L.) using multivariate technique. SAARC J Agri 8(1):70-78.

Lin CS, Binns MR (1988). A superiority measure of cultivar performance for cultivar x location data. Can J Plant Sci 68:193-198.

O'Leary N, Smith ME (1999). Breeding corn for adaptation to two diverse intercopping companions. Am J Alternat Agric 14:158-164.

Salardini AA, Sparrow LA, Holloway RJ (1992). Sweet corn responses to basal and top-dressed rate and sources of nitrogenous fertilizers. Austr J Agric Res 43:171-180.

Tonk FA, Ilker E, Tosun M (2011). Evaluation of genotype x environment interactions in maize hybrids using GGE biplot analysis. Crop Breed Appl Biotechnol 11:1-9.

http://www.agpm.com/pages/mais_doux.php. 